Article

\title{
Synthesis, Mass Spectroscopy Detection, and Density Functional Theory Investigations of the Gd Endohedral Complexes of $\mathrm{C}_{82}$ Fullerenols
}

\author{
Anastasia A. Shakirova ${ }^{1}$, Felix N. Tomilin ${ }^{1,2} \mathbb{D}$, Vladimir A. Pomogaev ${ }^{3,4}$, Natalia G. Vnukova ${ }^{1,2}$, \\ Grigory N. Churilov ${ }^{1,2}$, Nadezhda S. Kudryasheva ${ }^{1,5}{ }^{D}$, Olga N. Tchaikovskaya ${ }^{3}$, Sergey G. Ovchinnikov ${ }^{1,2}(\mathbb{D}$ \\ and Pavel V. Avramov 4,*
}

Citation: Shakirova, A.A.; Tomilin, F.N.; Pomogaev, V.A.; Vnukova, N.G.; Churilov, G.N.; Kudryasheva, N.S.; Tchaikovskaya, O.N.; Ovchinnikov, S.G.; Avramov, P.V. Synthesis, Mass Spectroscopy Detection, and Density Functional Theory Investigations of the Gd Endohedral Complexes of $C_{82}$ Fullerenols. Computation 2021, 9, 58 . https://doi.org/10.3390/

computation 9050058

Academic Editor: Karlheinz Schwarz

Received: 16 April 2021

Accepted: 12 May 2021

Published: 17 May 2021

Publisher's Note: MDPI stays neutral with regard to jurisdictional claims in published maps and institutional affiliations.

Copyright: (c) 2021 by the authors. Licensee MDPI, Basel, Switzerland. This article is an open access article distributed under the terms and conditions of the Creative Commons Attribution (CC BY) license (https:/ / creativecommons.org/licenses/by/ $4.0 /)$.
1 Department of Biophysics, School of Engineering Physics and Radio Electronics, School of Petroleum and Gas Engineering, Siberian Federal University, pr. Svobodny 79, 660041 Krasnoyarsk, Russia; anastasiya.shakirova.97@mail.ru (A.A.S.); felixnt@gmail.com (F.N.T.); nata_hd@rambler.ru (N.G.V.); churilov@iph.krasn.ru (G.N.C.); n-qdr@yandex.ru (N.S.K.); sgo@iph.krasn.ru (S.G.O.)

2 Krasnoyarsk Scientific Center, Kirensky Institute of Physics, Siberian Branch, Russian Academy of Sciences, Akademgorodok 50, 660036 Krasnoyarsk, Russia

3 Department of Physics, National Research Tomsk State University, Lenina Ave. 36, 634050 Toms, Russia; helper@gmail.com (V.A.P.); tchon@phys.tsu.ru (O.N.T.)

4 Department of Chemistry and Green-Nano Materials Research Center, Kyungpook National University, 80 Daehak-ro, Buk-gu, Daegu 41566, Korea

5 Krasnoyarsk Scientific Center, Institute of Biophysics, Siberian Branch, Russian Academy of Sciences, Akademgorodok 50/50, 660036 Krasnoyarsk, Russia

* Correspondence: paul.veniaminovich@knu.ac.kr

Abstract: $G d$ endohedral complexes of $C_{82}$ fullerenols were synthesized and mass spectrometry analysis of their composition was carried out. It was established that the synthesis yields a series of fullerenols $\mathrm{Gd} @ \mathrm{C}_{82} \mathrm{O}_{x}(\mathrm{OH})_{y}(x=0,3 ; y=8,16,24,36,44)$. The atomic and electronic structure and properties of the synthesized fullerenols were investigated using the density functional theory calculations. It was shown that the presence of endohedral gadolinium increases the reactivity of fullerenols. It is proposed that the high-spin endohedral fullerenols are promising candidates for application in magnetic resonance imaging.

Keywords: endohedral fullerenes; density functional theory; antioxidant activity; reactive oxygen species; magnetic resonance imaging

\section{Introduction}

Studies of the properties of fullerenes and fullerene derivatives made it possible to determine the areas of their applications [1-14], including biomedical ones. The main biomedical feature of fullerenes and most of their derivatives is the low toxicity and the ability to be removed from the body [4]. In particular, pristine fullerenes [15] demonstrated low toxicity without substantial health risks for prolonged exposure under good hygiene conditions. It was shown that $\mathrm{C}_{60}$ fullerenols demonstrate some toxicity due to the generation of reactive oxygen species caused by photoexcitation [16]. In particular, it was found that endohedral $\mathrm{Gd} @ \mathrm{C}_{82}(\mathrm{OH})_{22}$ species exhibited very low toxicity in tumor-bearing mice [17]. It was shown that most of the pristine and functionalized fullerenes are not overtly toxic, unless photoexcited or used at very high concentrations that are unlikely to be encountered environmentally or during therapy. The geometry and electronic structure of fullerenes allow them to form compounds containing various pharmacophore groups, which can easily pass to the excited state under the action of different physical and chemical factors and enclose metal atoms into their carbon cage with the formation of so-called endohedral metallofullerenes. The endohedral metal complexes are characterized by chemical stability, paramagnetism, and large specific surface, which can be easily functionalized [18]. 
Various functional groups can be attached to a fullerene cage, which makes it possible to obtain water-soluble fullerene derivatives. Fullerenols, due to their hydrophilic properties and ability to bind free radicals, can be used in chemotherapy, treatment of neurodegenerative diseases, and radiology $[4,8,9,18]$. Theoretical Molecular Dynamics (MD) simulations [19] of $\left[\mathrm{C}_{60}(\mathrm{OH})_{n}\right.$, where $\left.n=2-30\right]$ in aqueous solutions and survey of experimental data [20] demonstrate highly negative solvation free energies which directly indicate the thermodynamic feasibility of fullerenoles in water solutions.

In particular, hydroxylated fullerenes (fullerenols) exhibit pronounced antioxidant activity [3]. Fullerenols can react with most of the physiologically significant reactive oxygen species (ROS), including the $\mathrm{OH}^{\bullet}, \mathrm{O}_{2}{ }^{\bullet-}$, and $\mathrm{H}^{\bullet}$ radicals. Fullerenols can simultaneously contain the functional groups that can form radicals in aqueous solutions and anionic groups [4]. The calculation showed that the antioxidant activity with $\mathrm{OH}^{\bullet}$ depends on the distribution of hydroxyls over the $\mathrm{C}_{60}$ fullerene cage. The fullerenols, in which the hydroxyl distribution lowers the redox potential $\varepsilon$, have the high trapping activity.

A number of functional groups on the fullerene cage (carcass) are critical for the fullerenes biological activity. Eropkin and co-workers [21] studied the bioeffects of hydroxylated $\mathrm{C}_{60}$ fullerene derivatives $\mathrm{C}_{60}(\mathrm{OH})_{12-14}, \mathrm{C}_{60}(\mathrm{OH})_{18-24}, \mathrm{C}_{60}(\mathrm{OH})_{30-38}$. The authors did not find bioactivity of $\mathrm{C}_{60}(\mathrm{OH})_{12-14}$, while fullerenol $\mathrm{C}_{60}(\mathrm{OH})_{18-24}$ demonstrated maximal antiviral and protective properties. Kovel et al. [22] revealed a lower toxicity and higher antioxidant activity of fullerenols with fewer oxygen groups (24-28), as compared to fullerenols with the higher number of oxygen groups (40-42). The difference was attributed to the fullerenols catalytic activity via reversible electron acceptance, radical trapping, and balance of ROSs. Involvement of an exohedral atom of Fe to the structure of $\mathrm{C}_{60} \mathrm{O}_{2-4}(\mathrm{OH})_{20-24}$ increased its toxicity and decreased antioxidant activity [23]. The antioxidant effect of highly diluted fullerenol solutions on bacterial cells was attributed to hormesis phenomenon [24]. It was concerned with stimulation of adaptive response of cells under low-concentration exposures. Sequence analysis of $16 \mathrm{~S}$ ribosomal RNA was carried out in this study; it did not reveal mutations in bacterial DNA. Additionally, it was shown [25] that the antioxidant ability of natural detoxifying agent, humis substances, was lower and time-dependent, in contrast to fullerenol $\mathrm{C}_{60} \mathrm{O}_{2-4}(\mathrm{OH})_{20-24}$.

The Gd@ $\mathrm{C}_{82}$ endohedral fullerene complex and its derivatives are widely used in biomedicine [1-9]. The water-soluble gadolinium-containing metallofullerene derivatives can be excellent candidates to be used as novel magnetic resonance imaging (MRI) contrast agents, since they are characterized by the high relaxing ability and encapsulation of lanthanide ions $\left(\mathrm{Gd}^{3+}\right)$, which prevents their release into the bioenvironment [5]. The most widely used gadolinium-containing compounds are gadodiamide, gadopentetate dimeglumine, gadoterate meglumine, etc. [26,27]; however, there are fears that these substances may be toxic [27]. The metallofullerene derivatives trap toxic $\mathrm{Gd}^{3+}$ ions into an inert yet strong carbon cage preventing their release and exhibit the 10 to 40 times higher proton relaxation ability as compared with that of conventional contrast agents and, in some cases, the much longer retention of the glioma brain tumor in mouse models [28].

Gadolinium endohedral complex Gd@ $C_{82}$ increases the magnetic relaxivity of the contrast agent, which is a prerequisite for improved image contrast at lower gadolinium concentrations [29]. It was shown that Gd metallofullerenol in combination with chemotherapy improves the effectiveness of cancer therapy [30]. Gadolinium ions can inhibit calcium channels and exhibit neurological and cardiovascular toxicity [31]. To be used in clinical settings, the gadolinium ion must be placed in a chelating medium, which tightly binds the metal, but allows water to interact with unpaired gadolinium spins. The conventional approach implies the use of polyfunctional ligands, which strongly coordinate the $\mathrm{Gd}^{3+}$ ion, but allow at least one water molecule to directly bind to $\mathrm{Gd}^{3+}[5]$. Due to the complexity of the synthesis of fullerenols with the gadolinium guest atom inside a carbon cage, the use of these compounds is still limited. Nevertheless, the $\mathrm{Gd} @ \mathrm{C}_{82} \mathrm{O}_{x}(\mathrm{OH})_{y}$ fullerenol is a good candidate for biomedical applications, since it has good solubility in water. Gadolinium 
enclosed in a carbon cage becomes nontoxic due to the easy removal of fullerenols from the body. In addition, a fullerenol can act as a substance for struggling against the ROSs.

In this work, the density functional theory (DFT) calculations were used to study the equilibrium atomic geometry and electronic structure of Gd endohedral complexes of $\mathrm{C}_{82}$ fullerenols with different numbers of $\mathrm{O}$ and $\mathrm{OH}$ functional groups, which were synthesized in a high-temperature experiment and characterized by mass spectrometry. The reactivity of $\mathrm{Gd}_{0} \mathrm{C}_{82} \mathrm{O}_{x}(\mathrm{OH})_{y}$ endohedral complexes was estimated using the calculations of chemical electrophilicity $(\omega)$ and absolute electronegativity $(\chi)$ indices. It was found that the gadolinium guest atom increases the reactivity of fullerenol endohedral complexes with different ROSs. The endohedral complexes are proposed to be used for various MRI biomedical applications.

\section{Experimental Procedures}

A mixture of the $\mathrm{Gd}_{2} \mathrm{O}_{3}$ powder and graphite in a weight ratio of 1:1 was processed in high-frequency arc plasma discharge by sputtering of graphite electrodes with 3-mm axial holes [32] with very low chemical yield. Fullerene mixture was extracted from carbon condensate by carbon disulfide in a Soxhlet apparatus. Using the technique described by Akiyama et al., a mixture of $\mathrm{Gd}_{0} \mathrm{C}_{82}$ and higher fullerenes was isolated from the resulting solution. The sample was dried and redissolved in toluene. The $\mathrm{Gd}_{0} \mathrm{C}_{82}$ fullerene was isolated from the solution by high-efficiency liquid chromatography on Agilent Technologies 1200 Series chromatograph with the only one $\mathrm{Gd}_{0} \mathrm{C}_{82}$ endohedral complex detected in the mass spectrum, which signal clearly stands out against broadband background noise (Figure S1).

According to the method proposed by Chiang and co-workers [12], the -O and -OH groups were attached to the isolated endohedral metallofullerene. Taking into account that the number of $\mathrm{OH}$ groups attached to the fullerene must be even $[13,14]$, the composition of this product can be assumed as $\mathrm{Gd}_{\mathrm{C}} \mathrm{C}_{82} \mathrm{O}_{\mathrm{x}}(\mathrm{OH})_{\mathrm{y}}(x=10-12, y=30-32, x+y=40-42)$ [27].

\section{Computational Details}

The atomic and electronic structures of $\mathrm{C}_{82}$ fullerene, $\mathrm{Gd} @ \mathrm{C}_{82}$ endohedral complex, and $\mathrm{Gd} @ \mathrm{C}_{82} \mathrm{O}_{\mathrm{x}}(\mathrm{OH})_{\mathrm{y}}$ fullerenols and energy of solvation (Figure 1) were calculated using DFT meta-hybrid exchange correlation MN15 functional [33] and def(2)-SVP basis set [34] for carbon $(\mathrm{C})$, oxygen $(\mathrm{O})$, and hydrogen $(\mathrm{H})$ atoms and def(2)-SVP_ECP basis set for the gadolinium atom [35] using Gaussian 09 code [36]. The MN15 functional has a broader accuracy than any DFT potentials to reproduce bond energies, atomization energies, ionization potentials, electron affinities, proton affinities, reaction barrier heights, non-covalent interactions, hydrocarbon thermochemistry, isomerization energies, electronic excitation energies, absolute atomic energies, and molecular structures. In particular, it provides very accurate results for multi-, single-configurational, and non-covalent systems with mean unsigned error (MUE) 4.75, 1.85, and $0.25 \mathrm{kcal} / \mathrm{mol}$, respectively, which is several times smaller than MUEs of conventional DFT potentials. The def(2)-SVP basis set is a balanced basis set to provide split valence, triple zeta valence, and quadruple zeta valence quality for $\mathrm{H}$ to $\mathrm{Rn}$, which allows one to properly describe atomization energies, dipole moments, and structure parameters using density functional theory. The electronic structure calculations were performed within the restricted open-shell and unrestricted electronic structure calculations taking into account solvation effects using Universal solvation model based on density (SMD) [37]. Some details of taking into account solvation effects are presented in the SI Section. 
a)

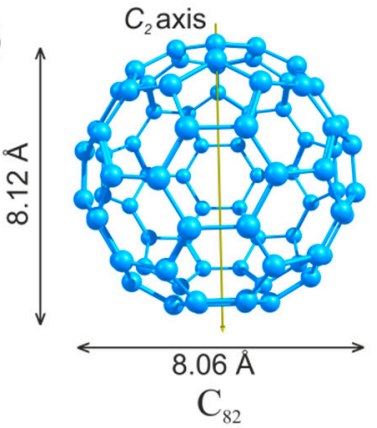

b)

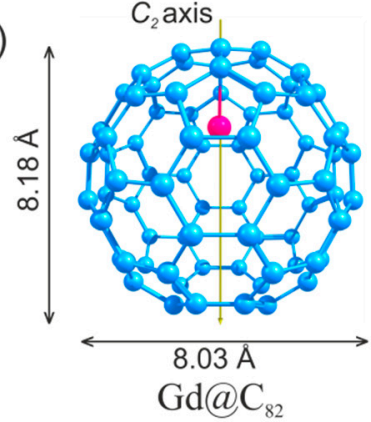

c)

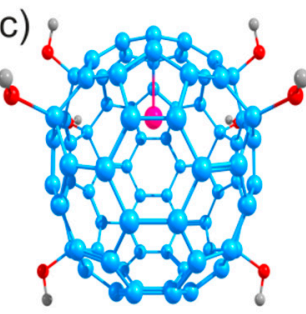

$\mathrm{Gd} @ \mathrm{C}_{82}(\mathrm{OH})_{8}$

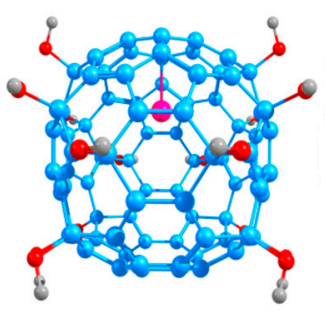

$\mathrm{Gd} @ \mathrm{C}_{82}(\mathrm{OH})_{16}$

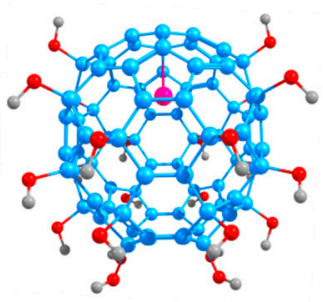

$\mathrm{Gd} @ \mathrm{C}_{82}(\mathrm{OH})_{24}$

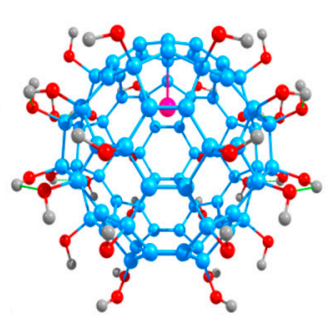

$\mathrm{Gd} @ \mathrm{C}_{82}(\mathrm{OH})_{36}$

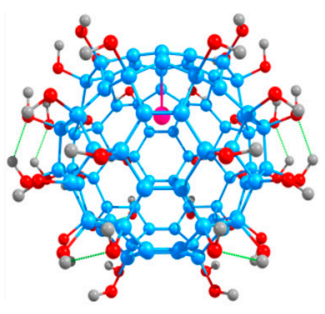

$\mathrm{Gd} @ \mathrm{C}_{82}(\mathrm{OH})_{44}$
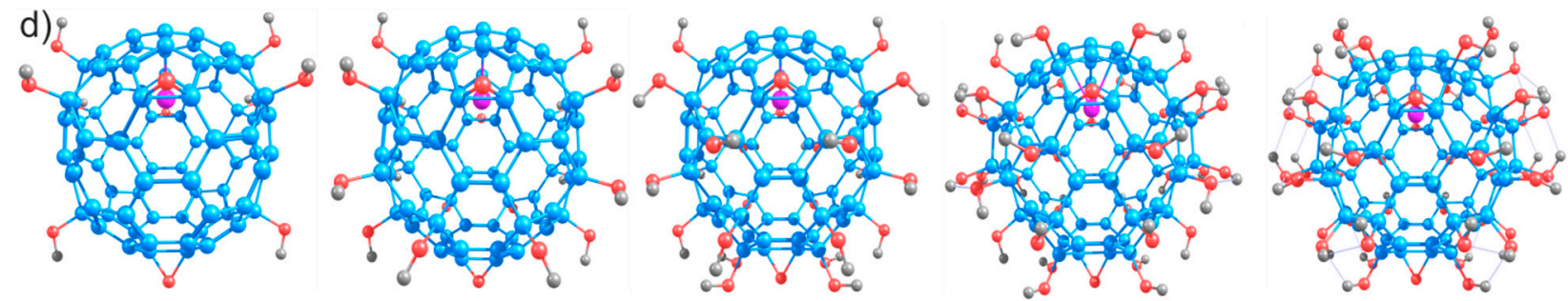

$\mathrm{Gd} @ \mathrm{C}_{82} \mathrm{O}_{3}(\mathrm{OH})_{8}$

$\mathrm{Gd} @ \mathrm{C}_{82} \mathrm{O}_{3}(\mathrm{OH})_{16}$

$\mathrm{Gd} @ \mathrm{C}_{82} \mathrm{O}_{3}(\mathrm{OH})_{24}$

$\mathrm{Gd} @ \mathrm{C}_{82} \mathrm{O}_{3}(\mathrm{OH})_{36}$

$\mathrm{Gd} @ \mathrm{C}_{82} \mathrm{O}_{3}(\mathrm{OH})_{44}$

Figure 1. $\mathrm{C}_{82}$ fullerene related clusters oriented following $\mathrm{C}_{2 \mathrm{v}}$ symmetry. (a) $\mathrm{C}_{82}$, (b) $\mathrm{Gd}_{\mathrm{C}} \mathrm{C}_{82}$, (c) $\mathrm{C}_{82} \mathrm{O}_{\mathrm{x}}(\mathrm{OH})_{\mathrm{y}}$, and (d) $\mathrm{Gd} @ \mathrm{C}_{82} \mathrm{O}_{\mathrm{x}}(\mathrm{OH})_{\mathrm{y}}(x=0,3 ; y=8,16,24,36,44)$. Carbon, gadolinium, oxygen, and hydrogen atoms are shown in blue, fuchsia, red, and gray colors, respectively. The carbon cage lengths along the second-order axis for $\mathrm{C}_{82}$ and $\mathrm{Gd} @ \mathrm{C}_{82}$ are 8.12 and $8.18 \AA$ with the widths 8.06 and $8.03 \AA$, respectively.

The Gd@ $C_{82}$ optimization was performed with spin $S=7 / 2$, which corresponds to $4 f^{7}$ configuration of $\mathrm{Gd}^{+3}$ ion [38] (Figure 1a,b). The symmetrically distributed $\mathrm{OH}$ groups over the Gd@C $C_{82}$ were employed to develop the atomistic models of different fullerenols and to calculate their atomic and electronic structures (Figure 1c). The fullerenols with three epoxy groups $\mathrm{Gd}_{0} \mathrm{C}_{82} \mathrm{O}_{3}(\mathrm{OH})_{y}(y=8,16,24,36,44$ (Figure 1d)) were developed by the uniform arrangement of hydroxyl and epoxy groups over fullerene carbon cage to reduce the number of possible intramolecular interactions and the atomic and electronic structures were studied as well. Some details of the development of structural models of Gd endohedral complexes of fullerenoles are presented in the SI Section.

To estimate the chemical reactivity of fullerenol gadolinium endohedral complexes, the absolute electronegativity index $\chi=(\mathrm{I}-\mathrm{A}) / 2(\mathrm{eV})[39]$, where $I$ is the energy of the highest occupied molecular orbital (HOMO) and $A$ is the energy of the lowest unoccupied molecular orbital (LUMO), and electrophilicity indexes $\omega=\chi^{2} / 2 \eta(\eta=-(\mathrm{I}-\mathrm{A}) / 2$ (in electron Volts, eV), which characterize the tendency of a molecule to attack the nucleophile, were calculated using the results of electronic structure calculations. The antioxidant properties of the fullerenols were estimated by calculating the electronic characteristics of oxygen molecules with different multiplicities $(m)$ and charges $(z)$, namely for $\mathrm{O}_{2}{ }^{-}$ $m=2$ and $\mathrm{z}=-1$; for $\mathrm{O}_{2}{ }^{0} m=1$ and $z=0$; for $\mathrm{O}_{2}{ }^{0} m=3$ and $z=0$; for hydrogen peroxide 
molecules $\mathrm{H}_{2} \mathrm{O}_{2} m=1$ and $z=0$; and for $\mathrm{HOO}^{\bullet} m=2$ and $z=0$. The density of states for fullerene and its derivatives were calculated with a peak smearing of $0.3 \mathrm{eV}$.

\section{Results and Discussion}

\subsection{The $\mathrm{C}_{82} \mathrm{O}_{x}(\mathrm{OH})_{y}$ and $\mathrm{Gd} @ \mathrm{C}_{82} \mathrm{O}_{x}(\mathrm{OH})_{y}$ Atomic Structures}

The Gd guest atom in the $\mathrm{Gd}_{1} \mathrm{C}_{82}$ endohedral complex is coordinated to the center of the hexagon on the $C_{2 v}$ axis of the $C_{82}$ cage [38]. An isolated $G d$ atom has the electron configuration $4 f^{7} 5 d^{1} 6 s^{2}$ and $\mathrm{Gd}^{3+}$ ion has a $4 f^{7}$ configuration, which points out that $\mathrm{Gd}$ $5 d$ - and $\mathrm{Gd} 6 s$-electrons are transferred to the carbon sphere, forming ionic bonds between $\mathrm{Gd}$ ion and $\mathrm{C}_{82}$ cage. The Gd $4 f^{7}$ configuration is consistent with the $\mathrm{Gd}^{3+} @ \mathrm{C}_{82}{ }^{3-}$ ion model [40]. The $\mathrm{Gd}_{\mathrm{C}} \mathrm{C}_{82}$ ground spin state results from the intramolecular antiferromagnetic exchange between gadolinium ion with spin $S_{\mathrm{Gd}}=7 / 2$ and $S_{\mathrm{C} 82}=1 / 2$ [38] with the total spin $S_{\mathrm{Gd} @ \mathrm{C} 82}=6 / 2$ of the complex.

The $C_{82}$ fullerene of $C_{2 v}$ symmetry consists of 12 pentagons and 32 hexagons (Figure $1 \mathrm{a}$, Table 1). The formation of $\mathrm{Gd}_{\mathrm{d}} \mathrm{C}_{82}$ leads to the elongation of some carbon-carbon bonds from 1.42-1.43 to $1.44-1.45 \AA(\Delta l=0.02 \AA$ ) (Table 1$)$. In fullerenols, the $C-C$ bond lengths are almost independent upon the number and positioning of the hydroxyl groups $(8,16$, and 24 ) on the fullerene cage $(l=1.38-1.42 \AA)$, as compared with pristine fullerene (Figure $2 \mathrm{a}$, Table 1). However, an increase in the number of hydroxyl groups to 36 and 44 significantly changes the bond length, thus the global $\mathrm{C}_{82} \pi$ system is almost annihilated with conversion of aromatic $C-C$ bonds to separate single and double bonds with increases of the length of the single bond from 1.41-1.42 to $1.51-1.53 \AA(\Delta l=0.10-0.12 \AA)$, while the length of the double bond decreases from $1.38-1.41$ to $1.33-1.35 \AA(\Delta l=0.06-0.08 \AA)$. In addition to the bond length, the angles between the carbon atoms of the carbon hexagon to which the gadolinium ion is coordinated also change, decreasing by 1-3 degrees in comparison with $\mathrm{C}_{82} \mathrm{O}_{\mathrm{x}}(\mathrm{OH})_{\mathrm{y}}$.

Table 1. Structural parameters * of $\mathrm{Gd} @ \mathrm{C}_{82} \mathrm{O}_{x}(\mathrm{OH})_{\mathrm{y}}$ and $\mathrm{C}_{82} \mathrm{O}_{x}(\mathrm{OH})_{y}$ complexes.

\begin{tabular}{|c|c|c|c|c|c|}
\hline \multirow{3}{*}{$\begin{array}{l}\text { Bond Lengths and } \\
\text { Bond Angles }\end{array}$} & \multicolumn{5}{|c|}{ Complexes } \\
\hline & \multicolumn{5}{|c|}{$\mathrm{C}_{82}(\mathrm{OH})_{\mathrm{y}}$} \\
\hline & $\mathrm{C}_{82}(\mathrm{OH})_{8}$ & $\mathrm{C}_{82}(\mathrm{OH})_{16}$ & $\mathrm{C}_{82}(\mathrm{OH})_{24}$ & $\mathrm{C}_{82}(\mathrm{OH})_{36}$ & $\mathrm{C}_{82}(\mathrm{OH})_{44}$ \\
\hline$l\left(C_{1}-C_{2}\right)$ & 1.42 & 1.41 & 1.42 & 1.53 & 1.53 \\
\hline$l\left(\mathrm{C}_{2}=\mathrm{C}_{3}\right)$ & 1.41 & 1.41 & 1.41 & 1.35 & 1.33 \\
\hline$\angle \mathrm{C}_{1-2-3}$ & 121 & 121 & 121 & 124 & 123 \\
\hline$\angle \mathrm{C}_{1-2-4}$ & 109 & 109 & 109 & 109 & 112 \\
\hline \multirow[t]{3}{*}{$\angle C_{3-2-4}$} & 122 & 122 & 121 & 118 & 122 \\
\hline & \multicolumn{5}{|c|}{$\mathrm{Gd} @ \mathrm{C}_{82}(\mathrm{OH})_{\mathrm{y}}$} \\
\hline & $\mathrm{Gd} @ \mathrm{C}_{82}(\mathrm{OH})_{8}$ & $\mathrm{Gd} @ \mathrm{C}_{82}(\mathrm{OH})_{16}$ & $\mathrm{Gd} @ \mathrm{C}_{82}(\mathrm{OH})_{24}$ & $\mathrm{Gd} @ \mathrm{C}_{82}(\mathrm{OH})_{36}$ & $\mathrm{Gd} @ \mathrm{C}_{82}(\mathrm{OH})_{44}$ \\
\hline$l\left(C_{1}-C_{2}\right)$ & 1.42 & 1.41 & 1.41 & 1.52 & 1.51 \\
\hline$l\left(C_{2}=C_{3}\right)$ & 1.41 & 1.41 & 1.40 & 1.35 & 1.33 \\
\hline$\angle \mathrm{C}_{1-2-3}$ & 119 & 120 & 120 & 121 & 122 \\
\hline$\angle \mathrm{C}_{1-2-4}$ & 108 & 109 & 109 & 109 & 113 \\
\hline \multirow[t]{3}{*}{$\angle C_{3-2-4}^{1-\angle-4}$} & 125 & 121 & 121 & 119 & 122 \\
\hline & \multicolumn{5}{|c|}{$\mathrm{C}_{82} \mathrm{O}_{x}(\mathrm{OH})_{y}$} \\
\hline & $\mathrm{C}_{82} \mathrm{O}_{3}(\mathrm{OH})_{8}$ & $\mathrm{C}_{82} \mathrm{O}_{3}(\mathrm{OH})_{16}$ & $\mathrm{C}_{82} \mathrm{O}_{3}(\mathrm{OH})_{24}$ & $\mathrm{C}_{82} \mathrm{O}_{3}(\mathrm{OH})_{36}$ & $\mathrm{C}_{82} \mathrm{O}_{3}(\mathrm{OH})_{44}$ \\
\hline$l\left(C_{1}-C_{2}\right)$ & 1.42 & 1.41 & 1.41 & 1.53 & 1.53 \\
\hline$l\left(\mathrm{C}_{2}=\mathrm{C}_{3}\right)$ & 1.41 & 1.41 & 1.41 & 1.35 & 1.33 \\
\hline$\angle \mathrm{C}_{1-2-3}$ & 121 & 121 & 120 & 124 & 123 \\
\hline$\angle \mathrm{C}_{1-2-4}$ & 109 & 109 & 109 & 109 & 113 \\
\hline$\angle C_{3-2-4}$ & 122 & 122 & 122 & 119 & 122 \\
\hline
\end{tabular}


Table 1. Cont.

\begin{tabular}{|c|c|c|c|c|c|}
\hline & \multicolumn{5}{|c|}{$\mathrm{Gd} @ \mathrm{C}_{82} \mathrm{O}_{x}(\mathrm{OH})_{\mathrm{y}}$} \\
\hline & $\mathrm{Gd} @ \mathrm{C}_{82} \mathrm{O}_{3}(\mathrm{OH})_{8}$ & $\mathrm{Gd} @ \mathrm{C}_{82} \mathrm{O}_{3}(\mathrm{OH})_{16}$ & $\mathrm{Gd} @ \mathrm{C}_{82} \mathrm{O}_{3}(\mathrm{OH})_{24}$ & $\mathrm{Gd} @ \mathrm{C}_{82} \mathrm{O}_{3}(\mathrm{OH})_{36}$ & $\mathrm{Gd} @ \mathrm{C}_{82} \mathrm{O}_{3}(\mathrm{OH})_{44}$ \\
\hline$l\left(\mathrm{C}_{1}-\mathrm{C}_{2}\right)$ & 1.42 & 1.42 & 1.41 & 1.53 & 1.52 \\
\hline$l\left(C_{2}=C_{3}\right)$ & 1.41 & 1.41 & 1.38 & 1.33 & 1.33 \\
\hline$\angle \mathrm{C}_{1-2-3}$ & 120 & 120 & 120 & 123 & 122 \\
\hline$\angle \mathrm{C}_{1-2-4}$ & 109 & 109 & 109 & 109 & 112 \\
\hline$\angle \mathrm{C}_{3-2-4}$ & 123 & 123 & 122 & 118 & 121 \\
\hline
\end{tabular}

$\mathrm{C}_{82}: l\left(\mathrm{C}_{1}-\mathrm{C}_{2}\right)=1.43, l\left(\mathrm{C}_{2}=\mathrm{C}_{3}\right)=1.42, \angle \mathrm{C}_{1-2-3}=121, \angle \mathrm{C}_{1-2-4}=108, \angle \mathrm{C}_{3-2-4}=121$;

$\mathrm{Gd} @ \mathrm{C}_{82}: l\left(\mathrm{C}_{1}-\mathrm{C}_{2}\right)=1.45, l\left(\mathrm{C}_{2}=\mathrm{C}_{3}\right)=1.44, \angle \mathrm{C}_{1-2-3}=121, \angle \mathrm{C}_{1-2-4}=107, \angle \mathrm{C}_{3-2-4}=121$

* Bond lengths $(\AA)$, bond angles $\left({ }^{\circ}\right)$.

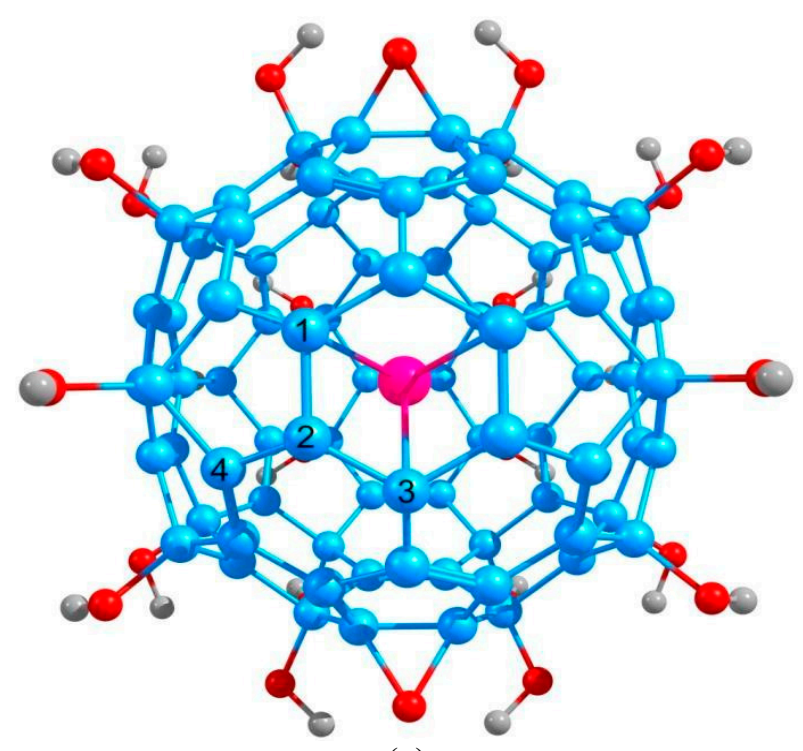

(a)

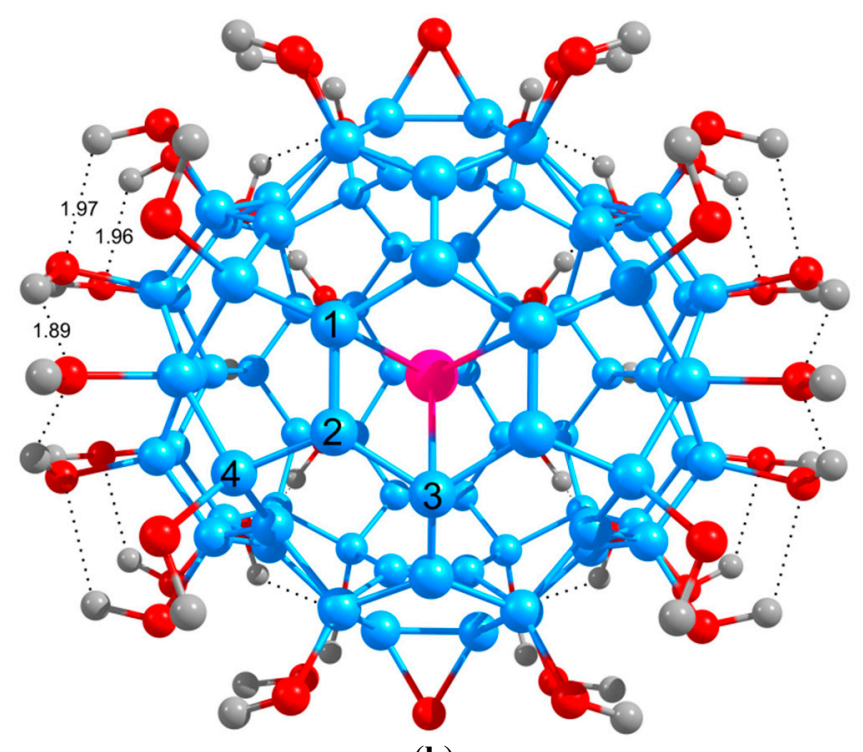

(b)

Figure 2. Atomic structure of $\mathrm{Gd}$ endohedral complexes of $\mathrm{C}_{82}$ fullerenols. (a) $\mathrm{Gd}_{\mathrm{C}} \mathrm{C}_{82} \mathrm{O}_{3}(\mathrm{OH})_{24}$ and $(\mathbf{b}) \mathrm{Gd}_{\mathrm{C}} \mathrm{C}_{82} \mathrm{O}_{3}(\mathrm{OH})_{44}$. Carbon, gadolinium, oxygen, and hydrogen atoms are presented in blue, fuchsia, red, and gray colors, respectively. Carbon atoms 1 and 2 are bonded through single bond, and carbon atoms 2 and 3 are bonded through double bond. (a) The bond lengths $l\left(\mathrm{C}_{1}-\mathrm{C}_{2}\right)$ and $l\left(\mathrm{C}_{2}=\mathrm{C}_{3}\right)$ in $\mathrm{Gd} @ \mathrm{C}_{82} \mathrm{O}_{3}(\mathrm{OH})_{24}$ are 1.41 and $1.38 \AA$, respectively. The bond angles $\angle \mathrm{C}_{1-2-3}, \angle \mathrm{C}_{1-2-4}$, and $\angle \mathrm{C}_{3-2-4}$ are $120^{\circ}, 109^{\circ}$, and $122^{\circ}$, respectively. (b) The bond lengths $l\left(\mathrm{C}_{1}-\mathrm{C}_{2}\right)$ and $l\left(\mathrm{C}_{2}=\mathrm{C}_{3}\right)$ in $\mathrm{Gd}_{\mathrm{O}} @ \mathrm{C}_{82} \mathrm{O}_{3}(\mathrm{OH})_{44}$ are 1.52 and $1.33 \AA$, respectively. The bond angles $\angle \mathrm{C}_{1-2-3}, \angle \mathrm{C}_{1-2-4}$, and $\angle \mathrm{C}_{3-2-4}$ are $122^{\circ}, 112^{\circ}$, and $121^{\circ}$, respectively. The dotted lines show the hydrogen bonds between hydrogen and oxygen atoms of different hydroxyl groups with bond lengths from 1.89 to $1.97 \AA$.

The presence of gadolinium ion combined with epoxy and hydroxyl groups $(8,16$ and 24 ) in the $\mathrm{C}_{82}$ fullerene slightly changes the bond angles between carbon atoms (Figure $2 \mathrm{a}$, Table 1). A greater number of hydroxyl groups increases the angle $\angle \mathrm{C}_{1-2-3}$ by $2-4^{\circ}$, from $120^{\circ}$ to $124^{\circ}, \angle \mathrm{C}_{1-2-4}$ increases by $3-4^{\circ}$, from $109^{\circ}$ to $112-113^{\circ}$, and $\angle \mathrm{C}_{3-2-4}$ decreases by $3-4^{\circ}$, for $x=36$ hydroxyl groups from $122-125^{\circ}$ to $118-119^{\circ}$. For $x=44$ hydroxyl groups, the angles increase by $3-4^{\circ}$, as compared with the fullerenols with 36 hydroxyl groups from $118-119^{\circ}$ to $121-122^{\circ}$.

It can be seen (Figures 1 and 2, Table 1) that $\mathrm{C}_{82} \mathrm{O}_{x}(\mathrm{OH})_{y}$ and $\mathrm{Gd}_{\mathrm{C}} \mathrm{C}_{82} \mathrm{O}_{x}(\mathrm{OH})_{y}(x=0$, $3 ; y=8,16,24,36,44)$ complexes can be assigned to two different groups, namely: (1) $x=0,3$ and $y=8,16,24$ and (2) $x=0,3 ; y=36,44$. In the first group, the $\pi$-system is maintained even in the presence of gadolinium ion in the carbon cage, which can be seen for the fullerenols from the change in the angle of the hexagon with the gadolinium ion coordinated to the center (a change by 0-2 degrees relative to that in $\mathrm{C}_{82}$ and $\mathrm{Gd} @ \mathrm{C}_{82}$ Figure $2 \mathrm{a}$, Table 1). However, as the number of hydroxyl groups increases, global $\mathrm{C}_{82}$ 
$\pi$-system is annihilated and uniform aromatic $\mathrm{C}-\mathrm{C}$ bonds are replaced by the single and double bonds, which leads to a change in the geometry of the carbon cage (Figure $2 b$, Table 1).

The presence of 8,16 , and 24 hydroxyl groups on $C_{82}$ carbon cage does not imply their significant mutual interaction (Figure 2a). When the number of hydroxyl groups increases to 36 and 44, they become close enough to each other and start interacting, forming a system of hydrogen bonds (Figure 2b). In particular, the distances between oxygen atoms of one hydroxyl group and hydrogen atoms of the other hydroxyl group ranges from 1.89 to $1.97 \AA$ (Figure $2 b$ ).

The electronic structure calculations show that in $\mathrm{C}_{82} \mathrm{O}_{x}(\mathrm{OH})_{y}$ complexes with 8,16 , and $24 \mathrm{OH}$ groups, the energy of interaction with solvent increases from 213 to $402 \mathrm{~kJ} / \mathrm{mol}$ (Table S1), whereas $\mathrm{Gd}_{0} \mathrm{C}_{82} \mathrm{O}_{\mathrm{x}}(\mathrm{OH})_{\mathrm{y}}$ complex solvation is energetically favorable for 16 hydroxyl groups $(793 \mathrm{~kJ} / \mathrm{mol}$, Table S1). An increase of the number of substituent hydroxyl groups in $\mathrm{C}_{82} \mathrm{O}_{x}(\mathrm{OH})_{y}$ and $\mathrm{Gd}_{0} \mathrm{C}_{82} \mathrm{O}_{\mathrm{x}}(\mathrm{OH})_{\mathrm{y}}(x=0,3 ; y=36,44)$ complexes leads to the formation of hydrogen bonds between oxygen and hydrogen atoms of the adjacent hydroxyl groups (the distance between hydroxyl groups decreased to 1.89-1.97 $\AA$; Figure $2 b$ ). The energy of solvation was calculated for the complexes with larger numbers of $\mathrm{C}_{82} \mathrm{O}_{8}(\mathrm{OH})_{y}(y=8,16,24,36,44)$ epoxy groups (Table S1). For the complexes with 8,16 , and $24 \mathrm{OH}$ groups, the energy of interaction with the solvent increases from 165 to $298 \mathrm{~kJ} / \mathrm{mol}$ (Table S1); for the complexes with 36 hydroxyl groups, it decreases to $258 \mathrm{~kJ} / \mathrm{mol}$; and for the complex with 44 hydroxyl groups, it increases to $288 \mathrm{~kJ} / \mathrm{mol}$ (Table S1). The presence of gadolinium ion further increases the energy of solvation to $712-793 \mathrm{~kJ} / \mathrm{mol}$. All fullerenoles have good solubility in water whether or not they have endohedral guest atom inside the $\mathrm{C}_{82}$ carbon cage. Consequently, for the complexes with a large number of hydroxyl groups, the interaction with the solvent is weaker (Table S1). The carbon cage is strongly distorted in the case of 36 and 44 hydroxyl groups, which leads to the breakdown of the $\pi$-system for the entire molecule and decreasing the electron affinity for the fullerenol, which is, according to the Koopmans theorem, the negative of LUMO energy, (Table 1, Figure 2b).

\subsection{The $\mathrm{C}_{82} \mathrm{O}_{x}(\mathrm{OH})_{y}$ and $\mathrm{Gd} @ \mathrm{C}_{82} \mathrm{O}_{x}(\mathrm{OH})_{y}$ Electronic Structures}

In Figure 3, the HOMO and LUMO diagrams are presented for free-standing $\mathrm{Gd}$ atom, $\mathrm{C}_{82}$ fullerene $\left(\mathrm{C}_{2 v}\right.$ symmetry) in gas phase, and $\mathrm{Gd} @ \mathrm{C}_{82}$, and $\mathrm{Gd}_{0} @ \mathrm{C}_{82} \mathrm{O}_{3}(\mathrm{OH})_{24}$ complexes in solvent as well as $\mathrm{O}_{2}{ }^{0}(m=1, m=3), \mathrm{O}_{2}{ }^{-}(m=2)$, and $\mathrm{HOO}^{\bullet}$ in the solvent.

The coordination type of epoxy groups of $\mathrm{C}_{82} \mathrm{O}_{3}(\mathrm{OH})_{24}$ fullerenols (Figures $\mathrm{S} 2$ and S3) slightly affects both HOMO and LUMO energies. In particular, the $\Delta E_{\text {(HOMO-LUMO) value }}$ for $\mathrm{C}_{82} \mathrm{O}_{3}(\mathrm{OH})_{24}$ is increased by $0.032 \mathrm{eV}$ relative to that of $\mathrm{C}_{82}(\mathrm{OH})_{24}$ (Figures S2 and S3), keeping spatial localization of the HOMO and LUMO orbitals almost intact. The $4 f \mathrm{Gd}$ electrons lie below HOMO by $1.88 \mathrm{eV}$ in the energy region from -6.24 to $-6.69 \mathrm{eV}$. The $\mathrm{HOMO}$ states are localized mainly on carbon atoms of the fullerenol (Figure $3 \mathrm{~b}-\mathrm{d}$ ), and, so the total high spin moment of the complex is maintained. The HOMO and LUMO of the $\mathrm{C}_{82}$ fullerene are located at the top of the carbon cage (Figure $3 \mathrm{~b}$ ). In the Gd endohedral complex, the localization of $\alpha$ and $\beta$ HOMOs is determined by endohedral gadolinium ion mostly at the top of the molecule in the vicinity of the carbon hexagon which coordinates $\mathrm{Gd}^{+3}$ (Figure 3c,d).

In this case, the spin-up and spin-down LUMOs are mostly localized at the carbon cage (Figure 3c). The hydroxy- and epoxy groups drive the localization of HOMOs and LUMOs states, i.e., the HOMO electron density is concentrated on carbon atoms near gadolinium and, vice versa, the LUMO electron density is localized at the opposite pole of the cage (Figure 3d). 


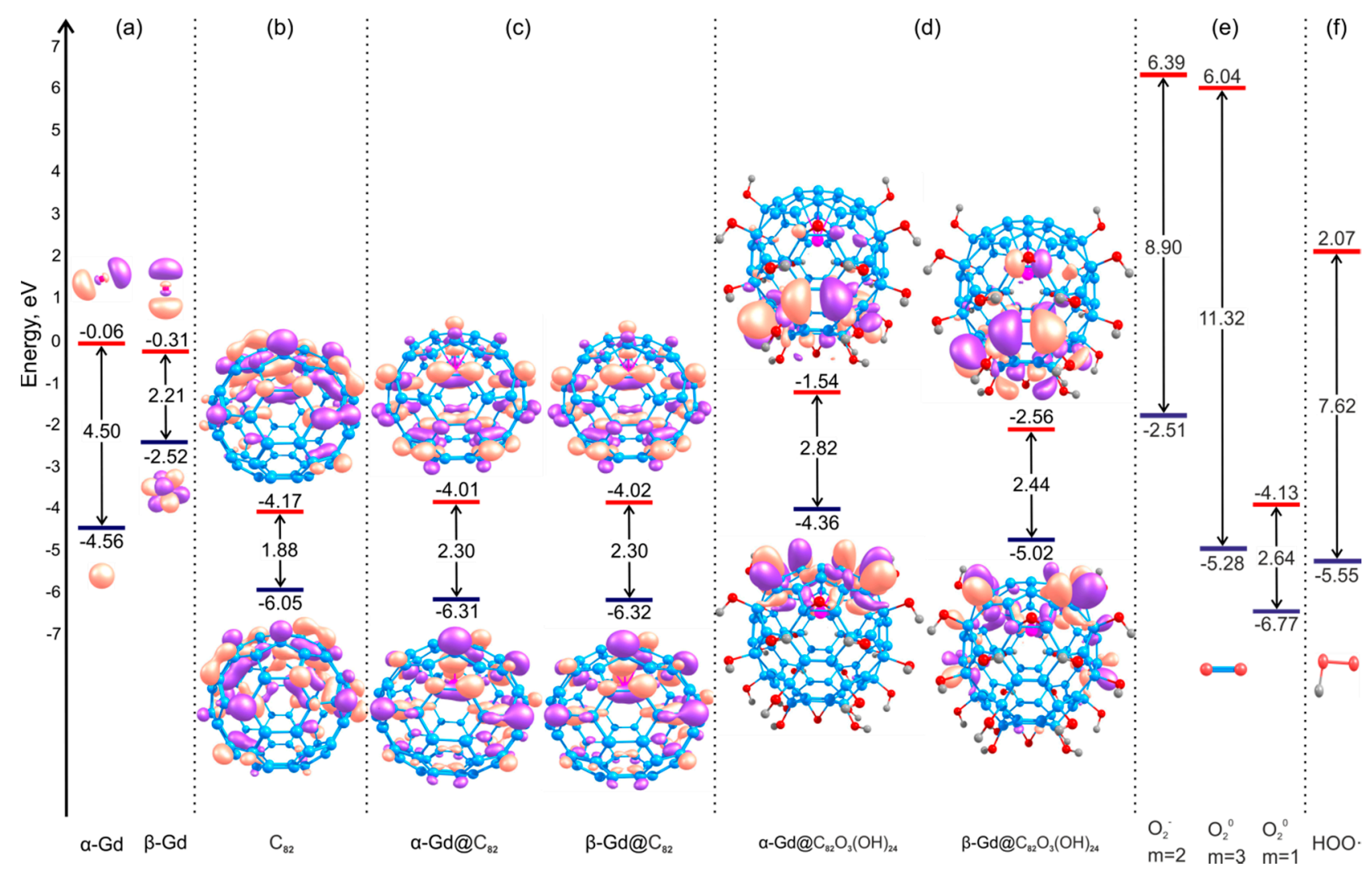

Figure 3. Diagram of the boundary molecular orbitals. (a) $\mathrm{Gd},(\mathbf{b}) \mathrm{C}_{82}$, (c) $\mathrm{Gd} @ \mathrm{C}_{82},(\mathbf{d}) \mathrm{Gd}_{\mathrm{C}} \mathrm{C}_{82} \mathrm{O}_{3}(\mathrm{OH})_{24},(\mathbf{e}) \mathrm{O}_{2}{ }^{0}(m=1$, $m=3), \mathrm{O}_{2}^{-}(m=2)$, and (f) $\mathrm{HOO}^{-}$in the solvent. The HOMO and LUMO levels are shown in blue and red colors, respectively. The number between the HOMO and LUMO is the energy gap ( $\Delta E_{\text {HOMO-LUMO }}$ ) in eV. The regions of the positive and negative wave functions on the molecules are shown in pink and purple colors.

Gadolinium ion slightly affects the energy shift of the occupied and unoccupied states. $\mathrm{HOMO}$ is shifted downwards by $0.26 \mathrm{eV}$ from -6.05 to $-6.31(-6.32) \mathrm{eV}$, whereas the LUMO is shifted upward by $0.10 \mathrm{eV}$ from -4.17 to $-4.01(-4.02) \mathrm{eV}$ with an energy gap increasing by $0.42 \mathrm{eV}$ from 1.88 to $2.30 \mathrm{eV}$ relative to the value for the free-standing $\mathrm{C}_{82}$ fullerene (Figure 3c). The coordination of epoxy and hydroxyl groups led to a shift of $\alpha$-HOMO upward by $1.95 \mathrm{eV}$ from -6.31 to $-4.36 \mathrm{eV}$ and shift of $\alpha$-LUMO upward by $2.47 \mathrm{eV}$ from -4.01 to $-1.54 \mathrm{eV}$ (Figure $3 \mathrm{~d}$ ). $\beta$-HOMO shifted upward by $1.3 \mathrm{eV}$ from -6.32 to $-5.02 \mathrm{eV}$ and $\beta$-LUMO also shifted upward by $1.46 \mathrm{eV}$ from -4.02 to $-2.56 \mathrm{eV}$ (Figure 3d). The energy gap for the $\beta$-electron of $\mathrm{Gd} @ \mathrm{C}_{82} \mathrm{O}_{3}(\mathrm{OH})_{24}$ is increased by $0.14 \mathrm{eV}$ from 2.30 to $2.44 \mathrm{eV}$ as compared with the pristine $\beta$-electron of $\mathrm{Gd} @ \mathrm{C}_{82}$.

Let us analyze the HOMO-LUMO behavior to elucidate the charge transfer mechanisms between fullerenoles and ROSes. The electronic structure of $\mathrm{O}_{2}$ and $\mathrm{HOO}^{-}$in different oxidation and spin states $\left(\mathrm{O}_{2}{ }^{-} m=2 ; \mathrm{O}_{2}{ }^{0} m=1 ; \mathrm{O}_{2}{ }^{0} m=3\right.$, Figure $\left.3 \mathrm{e}, \mathrm{f}\right)$ was previously studied by Dai et al. [41]. The $\mathrm{O}_{2}{ }^{-}$and $\mathrm{O}_{2} \mathrm{HOMO}$ energies $\left(\mathrm{O}_{2}{ }^{-}, m=2 ; \mathrm{O}_{2}{ }^{0}, m=3\right)$ are in the energy region of $-2.51 \div-5.28 \mathrm{eV}$ with the energy region for LUMOs between 6.39 to $6.04 \mathrm{eV}$. Relative to the electronic structure of $\mathrm{C}_{82} \mathrm{O}_{\mathrm{x}}(\mathrm{OH})_{\mathrm{y}}$ and $\mathrm{Gd}_{\mathrm{a}} \mathrm{C}_{82} \mathrm{O}_{\mathrm{x}}(\mathrm{OH})_{\mathrm{y}}$ $(x=0,3 ; y=8,16,24,36,44)$ fullerenols, the HOMO-LUMO energy gaps for $\mathrm{O}_{2}$ species are much greater than the UV threshold $(3.5 \mathrm{eV})$ and they are equal to 8.90 and $11.32 \mathrm{eV}$, respectively (Figure 3e). One can speculate that an electronic excitation that is less demanding in energy is an excitation from a reactive oxygen species to fullerenol LUMO states with alpha and beta energies equal to -1.54 and $-2.56 \mathrm{eV}$, respectively. For a neutral singlet oxygen molecule, the HOMO-LUMO gap is $2.64 \mathrm{eV}$; therefore, the excited electrons may be transferred to the fullerenole's LUMO state (Figure 3e). The energies of HOMO and LUMO states of the hydroxyperoxide radical $\mathrm{HOO}^{\bullet}$ are $-5.55 \mathrm{eV}$ and $2.07 \mathrm{eV}$, respectively, with the HOMO-LUMO gap equal to $7.62 \mathrm{eV}$ (Figure $3 \mathrm{f}$ ), which is also greater than the UV 
energy threshold. The $\alpha$ - and $\beta$-LUMO energies of fullerenol $\mathrm{Gd}_{\mathrm{L}} \mathrm{C}_{82} \mathrm{O}_{3}(\mathrm{OH})_{24}(-1.54$ and $-2.56 \mathrm{eV}$ for $\alpha$ and $\beta$ partners, Figure 3d) are also much lower than $\mathrm{HOO}{ }^{\bullet} \mathrm{LUMO}$. The ROS molecules have large energy gaps and their unoccupied molecular orbitals are high in energy, which complicates the excitations of the electron from HOMOs to LUMOs. The boundary molecular orbitals of fullerenols are located between HOMOs and LUMOs of the ROSes; therefore, these molecules can easily interact with the chemical environment.

The electrophilicity $\omega$ and absolute electronegativity $\chi$ indices of $\mathrm{Gd}_{0} \mathrm{C}_{82} \mathrm{O}_{x}(\mathrm{OH})_{y}$ and $\mathrm{C}_{82} \mathrm{O}_{x}(\mathrm{OH})_{y}$ complexes are presented in Table 2. $\mathrm{C}_{82} \mathrm{O}_{x}(\mathrm{OH})_{y}(x=0,3 ; y=16,24)$ exhibit no changes in the reactivity and their absolute electronegativity $\chi$ ranges from -4.5 to $-4.9 \mathrm{eV}$. The guest gadolinium ion causes a change in reactivity in both $\alpha$ and $\beta$ channels. In particular, the change in the properties of $\mathrm{Gd}_{0} @ \mathrm{C}_{82}(\mathrm{OH})_{y}(y=16,24)$ can be observed with absolute electronegativities $\chi$ from -3.8 and $-3.1 \mathrm{eV}$ for $\alpha$ electrons and from -5.1 to $-3.5 \mathrm{eV}-$ for $\beta$ electrons. Variations of the coordinates of epoxy groups do not lead to strong differences in reactivity between $\alpha$ and $\beta$ electrons. In particular, for 16 hydroxyl groups, the absolute electronegativities of $\alpha$ and $\beta$ electrons are $-3.2 \mathrm{eV}$, and for 24 hydroxyl groups, they are -2.9 and $-3.8 \mathrm{eV}$, respectively.

Table 2. Electrophilicity and absolute electronegativity indices of $\mathrm{Gd}_{\mathrm{C}} \mathrm{C}_{82} \mathrm{O}_{\mathrm{x}}(\mathrm{OH})_{\mathrm{y}}$ and $\mathrm{C}_{82} \mathrm{O}_{\mathrm{x}}(\mathrm{OH})_{\mathrm{y}}$ complexes.

\begin{tabular}{|c|c|c|c|c|c|c|}
\hline \multirow[t]{3}{*}{ Indexes } & \multicolumn{6}{|c|}{ Complexes } \\
\hline & \multicolumn{6}{|c|}{$\mathrm{C}_{82} \mathrm{O}_{\mathrm{x}}(\mathrm{OH})_{\mathrm{y}}$} \\
\hline & \multicolumn{2}{|c|}{$\mathrm{C}_{82} \mathrm{O}_{3}(\mathrm{OH})_{8}$} & \multicolumn{2}{|c|}{$\mathrm{C}_{82} \mathrm{O}_{3}(\mathrm{OH})_{16}$} & \multicolumn{2}{|c|}{$\mathrm{C}_{82} \mathrm{O}_{3}(\mathrm{OH})_{24}$} \\
\hline$\omega^{*}$ & \multirow{2}{*}{\multicolumn{2}{|c|}{$\begin{array}{c}7.3 \\
-4.8\end{array}$}} & \multirow{2}{*}{\multicolumn{2}{|c|}{$\begin{array}{c}5.2 \\
-4.5\end{array}$}} & \multirow{2}{*}{\multicolumn{2}{|c|}{$\begin{array}{c}11.6 \\
-4.8\end{array}$}} \\
\hline \multirow[t]{4}{*}{$x^{* *}$} & & & & & & \\
\hline & \multicolumn{6}{|c|}{$\mathrm{Gd}_{0} \mathrm{C}_{82} \mathrm{O}_{\mathrm{x}}(\mathrm{OH})_{\mathrm{y}}$} \\
\hline & \multicolumn{2}{|c|}{$\mathrm{Gd}_{\mathrm{C}} \mathrm{C}_{82} \mathrm{O}_{3}(\mathrm{OH})_{8}$} & \multicolumn{2}{|c|}{$\mathrm{Gd} @ \mathrm{C}_{82} \mathrm{O}_{3}(\mathrm{OH})_{16}$} & \multicolumn{2}{|c|}{$\mathrm{Gd}_{0} \mathrm{C}_{82} \mathrm{O}_{3}(\mathrm{OH})_{24}$} \\
\hline & $\alpha$ & $\beta$ & $\alpha$ & $\beta$ & $\alpha$ & $\beta$ \\
\hline$\omega$ & 13.0 & 6.5 & 5.7 & 5.8 & 3.1 & 5.8 \\
\hline$\chi$ & -4.3 & -4.6 & -3.2 & -3.2 & -2.9 & -3.8 \\
\hline
\end{tabular}

The $\mathrm{C}_{82} \mathrm{O}_{3}(\mathrm{OH})_{24}$ complex has an electrophilicity index of $\omega=11.6 \mathrm{eV}$, which promotes chemical attacks of ROS nucleophiles. The guest gadolinium ion changes the ability to accept electrons in both $\alpha$ and $\beta$ channels with $\omega=5.76 \mathrm{eV}$ for 16 hydroxyl groups and 3.1 and $5.86 \mathrm{eV}$ for 24 hydroxyl groups for $\alpha$ and $\beta$ electrons, respectively.

\section{Conclusions}

The $\mathrm{C}_{82} \mathrm{O}_{x}(\mathrm{OH})_{y}$ and $\mathrm{Gd}_{0} \mathrm{C}_{82} \mathrm{O}_{x}(\mathrm{OH})_{y}(x=0,3 ; y=8,16,24,36,44)$ complexes perspective for biomedical applications were synthesized and characterized using massspectroscopy. Following mass-spectrometry experimental detection, a number of atomistic models of endohedral fullerenoles $\mathrm{Gd}_{0} \mathrm{C}_{82} \mathrm{O}_{x}(\mathrm{OH})_{y}(x=0,3 ; y=8,16,24,36,44)$ were developed and studied using ab initio DFT calculations. It was shown that the guest Gd atom promotes the chemical reactivity and electrophilic properties of fullerenol cages. For a relatively small number of hydroxyl groups, the $\mathrm{C}_{82}$ carbon cage of $\mathrm{C}_{82} \mathrm{O}_{x}(\mathrm{OH})_{y}$ and $\mathrm{Gd} @ \mathrm{C}_{82} \mathrm{O}_{x}(\mathrm{OH})_{y}(x=0,3 ; y=24)$ complexes still maintain the $\pi$-electron system. The complexes display high electron affinity, which ensures advanced antioxidant properties. Increasing the number of hydroxyl groups $(y>24)$ in $\mathrm{Gd}_{0} \mathrm{C}_{82} \mathrm{O}_{x}(\mathrm{OH})_{y}$ complexes leads to the formation of intramolecular hydrogen bonds between the hydroxyl groups, which prevents chemical interactions with water solvent with decreasing of reactivity and solubility of the complexes with consequent degradation of antioxidant properties. Based on combined experimental and theoretical investigation, the endohedral $\mathrm{Gd}_{0} \mathrm{C}_{82} \mathrm{O}_{x}(\mathrm{OH})_{y}$ complexes with 24 hydroxyl groups are considered as the best candidate for biomedical applications. 
Supplementary Materials: The following are available online at https: / www.mdpi.com/article/ 10.3390 / computation9050058/s1, Figure S1: Mass spectrum of the chromatographic fraction with Gd@C82 (positive mode); Description of Solavatation models; Table S1: Energy of solvation of $\mathrm{Gd} @ \mathrm{C}_{82} \mathrm{O}_{3}(\mathrm{OH})_{\mathrm{y}}, \mathrm{C}_{82} \mathrm{O}_{3}(\mathrm{OH})_{\mathrm{y}}$ and $\mathrm{C}_{82} \mathrm{O}_{8}(\mathrm{OH})_{\mathrm{y}}$; Figure S2: Diagram of the boundary molecular orbitals of $\mathrm{C}_{82} \mathrm{O}_{\mathrm{x}}(\mathrm{OH})_{24}, \mathrm{Gd}_{\mathrm{C}} \mathrm{C}_{82} \mathrm{O}_{\mathrm{x}}(\mathrm{OH})_{24}(\mathrm{x}=0,3), \mathrm{O}_{20}(\mathrm{x}=1, \mathrm{x}=3), \mathrm{O}^{2-}(\mathrm{x}=2)$, and HOO• in the solvent $\left(\mathrm{H}_{2} \mathrm{O}\right)$. The HOMO and LUMO levels are shown in blue and red color, respectively. The number between the HOMO and LUMO is the energy gap ( $\triangle \mathrm{EHOMO}-\mathrm{LUMO}, \mathrm{eV}$ ); Figure S3. Densities of states of $\mathrm{Gd}_{\mathrm{C}} \mathrm{C}_{82} \mathrm{O}_{\mathrm{x}}(\mathrm{OH})_{\mathrm{y}}$. TDOS is total density of states, PDOS is partial density of states. Gd, $\mathrm{C}_{82}$ and $\mathrm{Gd} @ \mathrm{C}_{82}$ were calculated in gas phase, $\mathrm{Gd} @ \mathrm{C}_{82} \mathrm{O}_{3}(\mathrm{OH})_{24}$ in water solvent. (a) Gd: TDOS is shown in red color and multiplied by 0.5 , PDOS of $\alpha$ - $\beta$-channels are shown in blue and green colors, respectively; (b) $\mathrm{C}_{82}$ : TDOS is shown in blue color; (c) Gd@C $\mathrm{C}_{82}$ : TDOS is shown in red color and multiplied by 0.5 , PDOS of $\alpha$ - $\beta$-channels are shown in blue and green colors; (d) $\mathrm{Gd} @ \mathrm{C}_{82} \mathrm{O}_{3}(\mathrm{OH})_{24}$ : TDOS is shown in red color and multiplied by 0.5, PDOS of $\alpha$ - $ß$-channels are shown in blue and green colors. Dotted line shows HOMO-LUMO energy gap $\triangle \mathrm{E}$; Cartesian coordinates of all calculated complexes.

Author Contributions: Conceptualization, O.N.T., S.G.O. and P.V.A.; Synthesis of fullerenoles, N.G.V. and G.N.C.; Experimental study of biological activity, N.S.K.; Mass-spectroscopy characterization, A.A.S.; Quantum chemical calculations, F.N.T. and V.A.P. All authors have read and agreed to the published version of the manuscript.

Funding: The experimental results were funded by RFBR project No. 18-29-19003 MK. The quantum chemical study was funded by project 0721-2020-0033 of the Russian Ministry of Science and Education. The collaboration and coordination of Russian and Korean teams was supported by Collaborative NRF-RFBR grant (Korean ID: NRF-2019K2A9A1A06100125; Russian ID: Project No. 19-53-51005 NIFa RFFI-Korea) and NRF 2021R1A2C1010455 grant.

Institutional Review Board Statement: Not Applicable.

Informed Consent Statement: Not Applicable.

Data Availability Statement: All supporting data can be found in SI section available online.

Acknowledgments: The experimental results were funded by RFBR project No. 18-29-19003 MK. The quantum chemical study was funded by project 0721-2020-0033 of the Russian Ministry of Science and Education. The collaboration and coordination of Russian and Korean teams was supported by Collaborative NRF-RFBR grant (Korean ID: NRF-2019K2A9A1A06100125; Russian ID: Project No. 19-53-51005 NIFa RFFI-Korea) and NRF 2021R1A2C1010455 grant.

Conflicts of Interest: The authors declare no conflict of interest.

\section{References}

1. Popov, A.A.; Yang, S.; Dunsch, L. Endohedral Fullerenes. Chem. Rev. 2013, 113, 5989-6113. [CrossRef]

2. Shinohara, H. Endohedral metallofullerenes. Rep. Prog. Phys. 2000, 63, 843-892. [CrossRef]

3. Yang, S.; Wei, T.; Jin, F. When metal clusters meet carbon cages: Endohedral clusterfullerenes. Chem. Soc. Rev. 2017, 46, 5005-5058. [CrossRef] [PubMed]

4. Wang, Z.; Gao, X.; Zhao, Y. Mechanisms of Antioxidant Activities of Fullerenols from First-Principles Calculation. J. Phys. Chem. 2018, 122, 8183-8190. [CrossRef]

5. Zhang, J.; Ye, Y.; Chen, Y.; Pregot, C.; Li, T.; Balasubramaniam, S.; Hobart, D.B.; Zhang, Y.; Wi, S.; Davis, R.M.; et al. $\mathrm{Gd}_{3} \mathrm{~N}_{\mathrm{C}} \mathrm{C}_{84}(\mathrm{OH})_{\mathrm{x}}$ : A New Egg-Shaped Metallofullerene Magnetic Resonance Imaging Contrast Agent. J. Am. Chem. Soc. 2014, 136, 2630-2636. [CrossRef]

6. Da Ross, T. Twenty Years of Promises: Fullerene in Medicinal Chemistry. In Medicinal Chemistry and Pharmacological Potential of Fullerenes and Carbon Nanotubes; Cataldo, F., Da Ros, T., Eds.; Carbon Materials: Chemistry and Physics; Springer: Dordrecht, The Netherlands, 2008; Volume 1. [CrossRef]

7. Kang, S.G.; Huynh, T.; Zhou, R. Non-destructive Inhibition of Metallofullerenol Gd@ $\mathrm{C}_{82}(\mathrm{OH})_{22}$ on WW domain: Implication on Signal Transduction Pathway. Sci. Rep. 2012, 2, 957. [CrossRef]

8. Kang, S.G.; Zhou, G.; Yang, P.; Liu, Y.; Sun, B.; Huynh, T.; Meng, H.; Zhao, L.; Xing, G.; Chen, C.; et al. Molecular mechanism of pancreatic tumor metastasis inhibition by $\mathrm{Gd} @ \mathrm{C}_{82}(\mathrm{OH})_{22}$ and its implication for de novo design of nanomedicine. Proc. Natl. Acad. Sci. USA 2012, 109, 15431-15436. [CrossRef] [PubMed]

9. Meng, J.; Liang, X.; Chen, X.; Zhao, Y. Biological characterizations of $\left[\mathrm{Gd} @ \mathrm{C}_{82}(\mathrm{OH})_{22}\right]_{n}$ nanoparticles as fullerene derivatives for cancer therapy. Integr. Biol. 2013, 5, 43-47. [CrossRef] 
10. Churilov, G.N.; Kratschmer, W.; Osipova, I.V.; Glushenko, G.A.; Vnukova, N.G.; Kolonenko, A.L.; Dudnik, A.I. Sinthesis of fullerenes in a high-frequency arc plasma under elevated helium pressure. Carbon 2013, 62, 389-392. [CrossRef]

11. Akiyama, K.; Hamano, T.; Nakanishi, Y.; Takeuchi, E.; Noda, S.; Wang, Z.; Kubuki, S.; Shinohara, H. Non-HPLC rapid separation of metallofullerenes and empty cages with $\mathrm{TiCl}_{4}$ Lewis acid. J. Am. Chem. Soc. 2012, 134, 9762-9767. [CrossRef] [PubMed]

12. Chiang, L.Y.; Swirczewski, J.W.; Hsu, C.S.; Chowdhury, S.K.; Cameron, S.; Creegan, K. Multi-hydroxy additions onto $\mathrm{C}_{60}$ fullerene molecules. J. Chem. Soc. Chem. Commun. 1992, 114, 1791-1793. [CrossRef]

13. Shilin, V.A.; Szhogina, A.A.; Suyasova, M.V.; Sedov, V.P.; Lebedev, V.T.; Kozlov, V.S. Fullerenes and fullerenols survival under irradiation. Nanosystems 2016, 7, 146-152. [CrossRef]

14. Wang, B.C.; Wang, H.W.; Tso, H.C.; Chen, T.L.; Chou, Y.M. Theoretical studies of $\mathrm{C}_{70}(\mathrm{OH})_{\mathrm{n}}(\mathrm{n}=14,16,18$ and 20) fullerols. J. Mol. Struct. THEOCHEM 2002, 581, 177-186. [CrossRef]

15. Aschberger, K.; Johnston, H.J.; Stone, V.; Aitken, R.J.; Tran, C.L.; Hankin, S.M.; Peters, S.A.K.; Christensen, F.M. Review of fullerene toxicity and exposure-Appraisal of a human health risk assessment, based on open literature. Regul. Toxicol. Pharmacol. 2010, 58, 455-473. [CrossRef] [PubMed]

16. Trpkovic, A.; Todorovic-Markovic, B.; Trajkovic, V. Toxicity of pristine versus functionalized fullerenes: Mechanisms of cell damage and the role of oxidative stress. Arch. Toxicol. 2012, 86, 1809-1827. [CrossRef] [PubMed]

17. Chen, C.; Xing, G.; Wang, J.; Zhao, Y.; Li, B.; Tang, J.; Jia, G.; Wang, T.; Sun, J.; Xing, L. Multihydroxylated [Gd@C $\left.82(\mathrm{OH})_{22}\right]_{n}$ Nanoparticles: Antineoplastic Activity of High Efficiency and Low Toxicity. Nano Lett. 2005, 5, 2050-2057. [CrossRef] [PubMed]

18. Chen, Z.; Ma, L.; Liu, Y.; Chen, C. Applications of Functionalized Fullerenes in Tumor Theranostics. Theranostics 2012, 2, 238-250. [CrossRef]

19. Keshri, S.; Tembe, B.L. Thermodynamics of hydration of fullerols $[\mathrm{C} 60(\mathrm{OH}) \mathrm{n}]$ and hydrogen bond dynamics in their hydration shells. J. Chem. Phys. 2017, 146, 074501. [CrossRef]

20. Djordjevic, A.; Srdjenovic, B.; Seke, M.; Petrovic, D.; Injac, R.; Mrdjanovic, J.J. Review of synthesis and antioxidant potential of fullerenol nanoparticles. J. Nanomater. 2015, 2015, 567073. [CrossRef]

21. Eropkin, M.Y.; Melenevskaya, E.Y.; Nasonova, K.V.; Bryazzhikova, T.S.; Eropkina, E.M.; Danilenko, D.M.; Kiselev, O.I. Synthesis and biological activity of fullerenols with various contents of hydroxyl groups. Pharm. Chem. J. 2013, 47, 87-91. [CrossRef]

22. Kovel, E.S.; Sachkova, A.S.; Vnukova, N.G.; Churilov, G.N.; Knyazeva, E.M.; Kudryasheva, N.S. Antioxidant activity and toxicity of fullerenols via bioluminescence signaling: Role of oxygen substituents. Int. J. Mol. Sci. 2019, 20, 2324. [CrossRef]

23. Kudryasheva, N.S.; Kovel, E.S.; Sachkova, A.S.; Vorobeva, A.A.; Isakova, V.G.; Churilov, G.N. Bioluminescent enzymatic assay as a tool for studying antioxidant activity and toxicity of bioactive compounds. Photochem. Photobiol. 2017, 93, 536-540. [CrossRef] [PubMed]

24. Sachkova, A.S.; Kovel, E.S.; Churilov, G.N.; Guseynov, O.A.; Bondar, A.A.; Dubinina, I.A.; Kudryasheva, N.S. On mechanism of antioxidant effect of fullerenols. Biochem. Biophys. Rep. 2017, 9, 1-8. [CrossRef]

25. Sachkova, A.S.; Kovel, E.S.; Churilov, G.N.; Stom, D.I.; Kudryasheva, N.S. Biological activity of carbonic nano-structurescomparison via enzymatic bioassay. J. Soils Sediments 2019, 19, 2689-2696. [CrossRef]

26. Maravilla, K.R.; San-Juan, D.; Kim, S.J.; Elizondo-Riojas, G.; Fink, J.R.; Escobar, W.; Bag, A.; Roberts, D.R.; Hao, J.; Pitrou, C.; et al. Comparison of Gadoterate Meglumine and Gadobutrol in the MRI Diagnosis of Primary Brain Tumors: A Double-Blind Randomized Controlled Intraindividual Crossover Study (the REMIND study). Am. J. Neuroradiol. 2017, 38, 1681-1688. [CrossRef]

27. Ersoy, H.; Rybicki, F.J. Biochemical Safety Profiles of Gadolinium-Based Extracellular Contrast Agents and Nephrogenic Systemic Fibrosis. J. Magn. Reson. Imaging. 2007, 26, 1190-1197. [CrossRef]

28. Guan, M.; Ge, J.; Wu, J.; Zhang, G.; Chen, D.; Zhang, W.; Zhang, Y.; Zou, T.; Zhen, M.; Wang, C.; et al. Fullerene/photosensitizer nanovesicles as highly efficient and clearable phototheranostics with enhanced tumor accumulation for cancer therapy. Biomaterials 2016, 103, 75-85. [CrossRef]

29. Rodriguez-Galvan, A.; Rivera, M.; Garcia-Lopez, P. Gadolinium-containing carbon nanomaterials for magnetic resonance imaging: Trends and challenges. J. Cell. Mol. Med. 2020, 24, 3779-3794. [CrossRef]

30. Tang, J.; Zhang, R.; Guo, M. Gd-metallofullerenol drug delivery system mediated macrophage polarization enhaces the efficiency of chemotherapy. J. Control. Release 2020, 320, 293-303. [CrossRef] [PubMed]

31. Clavaguéra, C.; Sansot, E.; Calvo, F.; Dognon, J.P. Gd(III) polyaminocarboxylate chelate: Realistic many-body molecular dynamics simulations for molecular imaging applications. J. Phys. Chem. 2006, 110, 12848-12851. [CrossRef]

32. Dudnik, A.I.; Vnukova, N.G.; Drokin, N.A.; Bondarev, V.S.; Shestakov, N.P.; Tomashevich, Y.V.; Churilov, G.N. Electrophysical properties of hydroxylated endohedral metallofullerene with gadolinium. J. Phys. Chem. Solids. 2019, 135, 109094. [CrossRef]

33. Yu, H.S.; He, X.; Li, S.L.; Truhlar, D.G. MN15: A Kohn-Sham global-hybrid exchange-correlation density functional with broad accuracy for multi-reference and single-reference systems and noncovalent interactions. Chem. Sci. 2016, 7, 5032-5051. [CrossRef]

34. Weigend, F; Ahlrichs, R. Balanced basis sets of split valence, triple zeta valence and quadruple zeta valence quality for $H$ to Rn: Design and assessment of accuracy. Phys. Chem. 2005, 7, 3297. [CrossRef] [PubMed]

35. Gulde, R.; Pollak, P.; Weigend, F. Error-Balanced Segmented Contracted Basis Sets of Double- $\zeta$ to Quadruple- $\zeta$ Valence Quality for the Lanthanides. J. Chem. Theory Comput. 2012, 8, 4062-4068. [CrossRef]

36. Frisch, M.J. Gaussian 09, Revision A, 1st ed.; Gaussian, Inc.: Wallingford, CT, USA, 2009. 
37. Marenich, A.V.; Cramer, C.J.; Truhlar, D.G. Universal solvation model based on solute electron density and a continuum model of the solvent defined by the bulk dielectric constant and atomic surface tensions. J. Phys. Chem. 2009, 113, 6378-6396. [CrossRef] [PubMed]

38. Dolg, M.; Stoll, H.; Preuss, H. Energy-adjusted ab initio pseudopotentials for the rare earth elements. J. Chem. Phys. 1989, 90, 1730-1734. [CrossRef]

39. Pearson, R.G. Chemical Hardness: Applications from Molecules to Solids; Wiley: Weinheim, Germany, 1997.

40. Nishibori, E.; Iwata, K.; Sakata, M.; Takata, M.; Tanaka, H.; Kato, H.; Shinohara, H. Anomalous endohedral structure of Gd@C82 metallofullerenes. Phys. Rev. 2004, 69, 113412. [CrossRef]

41. Dai, X.; Gao, Y.; Xin, M.; Wang, Z.; Zhou, R. The ground state and electronic structure of Gd@C82: A systematic theoretical investigation of first principle density functional. J. Chem. Phys. 2014, 141, 244306. [CrossRef] 